\title{
Endogenous Activity Rhythms of Larval Fish Assemblages in a Mangrove- fringed Estuary in North Brazil
}

\author{
Mário Barletta $^{1,2^{*}}$ and Audrey Barletta-Bergan ${ }^{3}$ \\ ${ }^{1}$ Present address: Laboratory of Ecology and Management of Estuarine and Coastal Ecosystems, Departamento de \\ Oceanografia, UFPE, Cidade Universitária, 50740-550, Recife, Pernambuco, Brazil \\ ${ }^{2}$ Instituto de Ecologia e Gerenciamento de Ecossistemas Aquáticos (IEGEA). P.O. Box: 8132, Recife, 51020-970, Per- \\ nambuco, Brazil \\ ${ }^{3}$ Centre for Tropical Marine Ecology (ZMT), Fahrenheitstrasse 6, 28359 Bremen, Germany
}

\begin{abstract}
In Caeté Estuary, the decrease of larval abundance downstream was attributed to reduced retention, since ebb tide densities prevailed mainly in the middle and lower estuary during the rainy season due to increased freshwater outflow. Anchovia clupeoides, Stellifer microps and Guavina guavina were most abundant in the late dry season on flood tides in the upper estuary, whereas ebb tide densities of these species prevailed in other regions. Environmental fluctuations associated with lunar periodicity, such as tidal amplitude, may account for weekly variability of recruitment and reproduction of some fish species. A. clupeoides showed increased spawning activity during first quarter moon, whereas new moon phases seemed to be reproduction periods of Cynoscion acoupa. Vertical migration was not employed by the most abundant species to enable river retention, since larval densities of these species were not significantly higher at the bottom on ebb tides, except for C. acoupa and Stellifer rastrifer. This result may be related to system turbulence or to the dominance of younger stages unable to migrate vertically at the time of sampling. Lateral movement to the river bank is proposed as a possible retention mechanism. Diel effects on larval abundance related to trophic activity and gear avoidance.
\end{abstract}

Key Words: Fishes larvae assemblages, estuary, mangrove, Brazil, temporal and spatial variation.

\section{INTRODUCTION}

Many studies on larval fishes have concentrated on elucidating the way in which marine species are transported into estuaries [1-3]. Typically, the circulation in estuaries provides an outflow of fresh or brackish water over the incoming wedge of saline water [4]. This two-layered circulation pattern allows for passive transport of offshore-spawned species at the bottom of the water column upstream to nursery areas using tidal flows as a primary transport mechanism [5]. "Selective tidal stream transport" is a mechanism whereby organisms can maintain a certain position in estuaries, or achieve net upstream movement, by active vertical movement [6]. Organisms enter the water column while the tidal flow is in the direction of upstream migration, and leave when it is in the opposite direction [7]. Endogenous activity rhythms are also important in recruitment to estuarine nursery areas [5]. Some organisms have evolved elaborate behavioural patterns that increase the chances of entering estuaries. However, until very recently, no studies on estuarine larval fish communities were made in North Brazil $[8,9]$. The aims of the present study were to assess the influence of lunar

*Address correspondence to this author at the Laboratory of Ecology and Management of Estuarine and Coastal Ecosystems, Departamento de Oceanografia, UFPE, Cidade Universitária, 50740-550, Recife, Pernambuco, Brazil; Tel/Fax: +558121268225

E-mail: mario.barletta@pq.cnpq.br cycles on the composition and abundance of fish larvae in a tropical estuary and; to give insight into the factors influencing reproduction. Possible retention mechanisms were examined, investigating the abundance and composition of the larval fish community at the different combinations of tide, daytime, and layer.

\section{MATERIALS AND METHODOLOGY}

\section{Study Site}

The Caeté Estuary is situated in the State of Pará, North Brazil, about $200 \mathrm{~km}$ southeast of Belém. During the rainy season, increased freshwater runoff from Caeté and Urumajó rivers reduces salinity in the Caeté Estuary. During the dry season marine waters with higher salinity prevail [10]. Fairly strong tidal currents result in almost no vertical salinity gradient in the Caeté Estuary [11]. Sampling stations were situated along a transect in Caeté River Estuary spread in three zones $(a, b, c)$ based on the salinity gradient of the estuary (Fig. 1).

\section{Sampling Methods}

A conical plankton net $(300 \mu \mathrm{m}, 60 \mathrm{~cm}$ mouth $\varnothing, 2 \mathrm{~m}$ long) was equipped with a digital flow meter (Oceanics), which measured the filtered water volume. Each sampling consisted of a 10 minutes haul. A combination of weights and floats allowed positioning the net near the bottom or at 


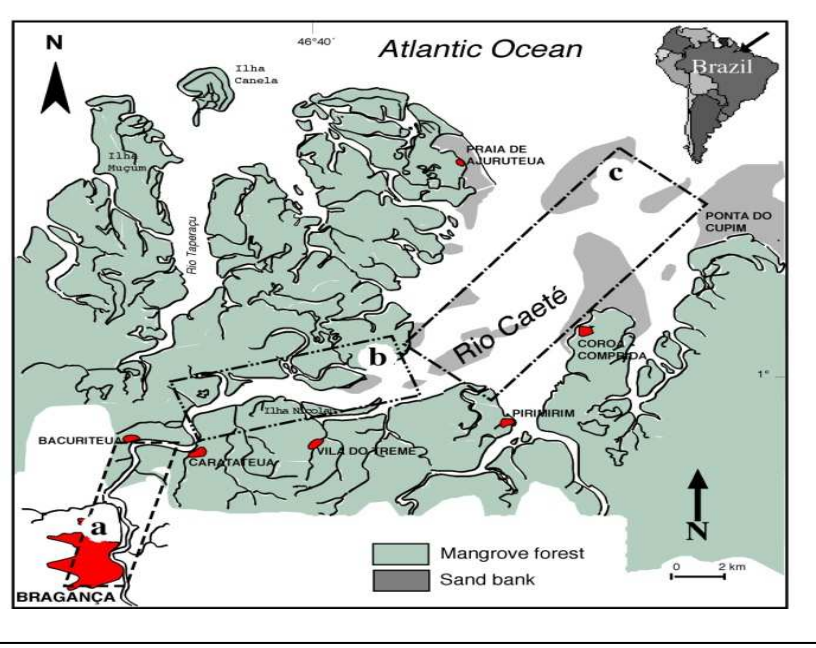

Fig. (1). Study area, showing the position of the three sampling areas $\mathrm{a}, \mathrm{b}$ and $\mathrm{c}$ in the Caeté Estuary, corresponding to the upper, middle and lower reaches of the estuary.

the water surface, respectively. Three bottom and three surface hauls were performed monthly in each region of the Caeté River Estuary on successive ebb and flood tides at approximately 6 hours intervals from July 1996 to September 1997. One sampling unit is constituted of three months with three replicates per tide in each region, resulting in nine replicates per unit. Additionally, sampling was carried out four times a month in September 1996 (end of dry season) and March 1997 (end of rainy season) to take the four different lunar phases into account. These months were chosen for collection as the highest spring and the lowest neap tide occur in this period. Six ichthyoplankton samples were collected each month in the upper region of the estuary (a), because of strong currents in the other zones, especially during full- and new moon. A sampling unit is constituted of two months per moon phase, resulting in a total of 96 sampling deployments. Moreover, 30-h sampling sessions were undertaken in December 1996 (dry season) and June 1997 (rainy season) during first quarter moon, since the lowest tideraising forces are created in this period. Sampling stations were located in the middle reaches of the Caeté Estuary, because of its proximity to the mangrove forest. Each sampling trip consisted of a surface set followed immediately by a bottom set on consecutive ebb and flood tides for a period of 30 hours. The total number of samples amounted to 72 (i.e. four tidal periods with three top and three bottom samples during each tidal period). During all sampling procedures, surface salinity (WTW LF 197), temperature, current and depth were monitored. Samples were immediately fixed in $4 \%$ buffered formalin in seawater.

\section{Laboratory Procedures}

The number of individuals per taxon were counted from the entire sample and then converted to a standard water amount of $100 \mathrm{~m}^{3}$. Species identification was done using the appropriate literature from [12-28]. The ichthyoplankton were categorised in developmental stages, according to that previously proposed in the specialized literature [29]. Body length was measured to the nearest $0.1 \mathrm{~mm}$. Size-frequency histograms based on pooled data were constructed for the dominant species for each sampling session.
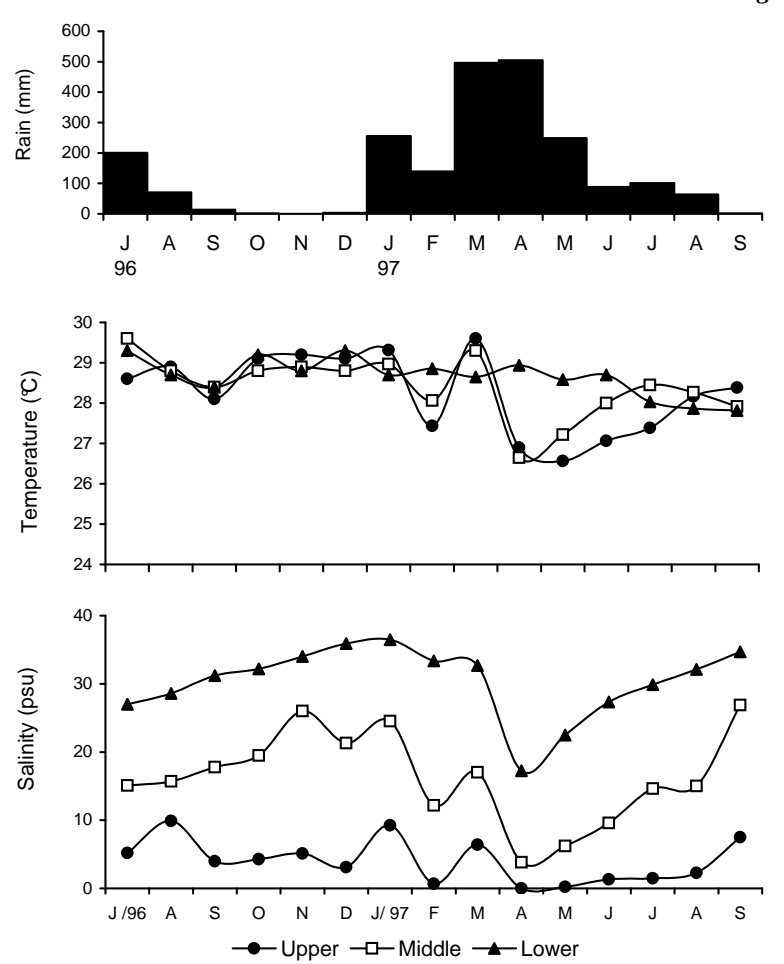

Fig. (2). Monthly means of the environmental variables of surface samples in the upper, middle and lower reaches of the Caeté Estuary, for the study period.

\section{Statistical Analysis}

Differences in number of species, total densities and densities of the most abundant species between sites, depths, time of the day, tidal periods and moon phases were tested for significance using two- or three-way analysis of variance (ANOVA). Since the abundance matrix contained many zero values, the raw data were $\log$-transformed $\left[\log _{10}(\mathrm{X}+1)\right]$ so their distributions approached normality. The assumption of homogeneity of variance was tested using Bartlett's $\mathrm{Chi}^{2}$ test. Since the variance was still often heterogeneous, conclusions from the results of ANOVAs have concentrated on those cases where significant levels were less than 0.01 [30]. Where ANOVA showed a significant difference, an a posteriori Student-Newman-Keuls (SNK) test was used to determine which means were significantly different at the 0.05 level of probability [30].

\section{RESULTS}

\section{Environmental Variables}

\section{Tidal Study}

The upper estuary is shallower (mean: $4.7 \mathrm{~m}$ ), has lower salinities (0-10), stronger ebb and flood currents (55.6 and $43.6 \mathrm{~cm} . \mathrm{s}^{-1}$, respectively), and more variable temperatures $\left(26.6-29.6^{\circ} \mathrm{C}\right)$, than the other regions. The middle estuary can be classified as an intermediate between the two other regions (salinities of $3.8-26.9$ ). The lower estuary is deepest (mean: $7.1 \mathrm{~m})$, has highest salinities $(17.2-36.5)$, weaker ebb and flood currents $(31.4$ and $24.4 \mathrm{~cm} / \mathrm{s})$, and less variable temperatures $\left(27.8-29.3^{\circ} \mathrm{C}\right)$. Salinity underwent very pronounced seasonal changes between April 1997 and September 1997, except for the upper reaches of the estuary (Fig. 2). The low salinity in the late rainy season was due to 


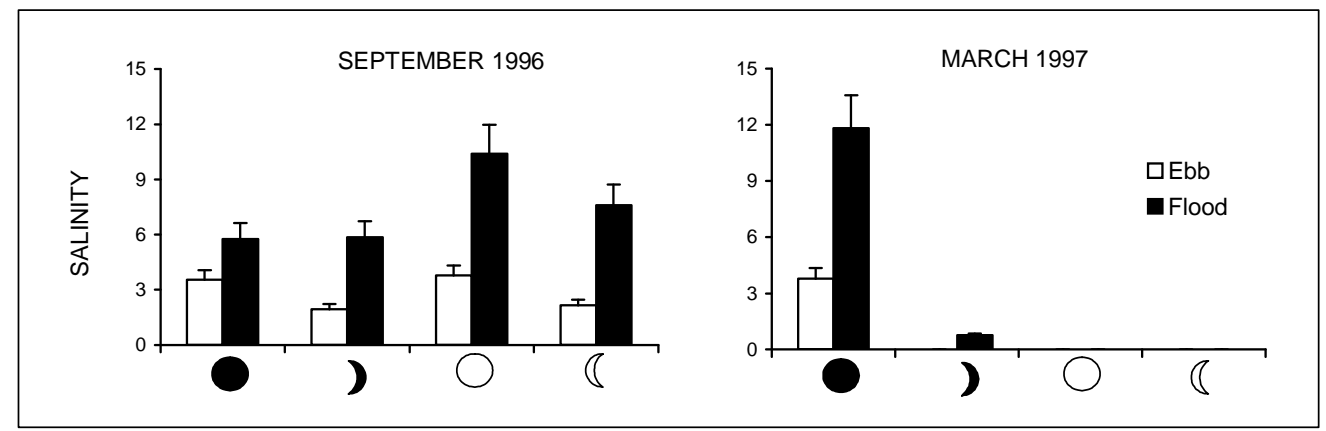

Fig. (3). Mean salinity during the different lunar phases in September 1996 and March 1997 in the upper reaches of Caeté River.

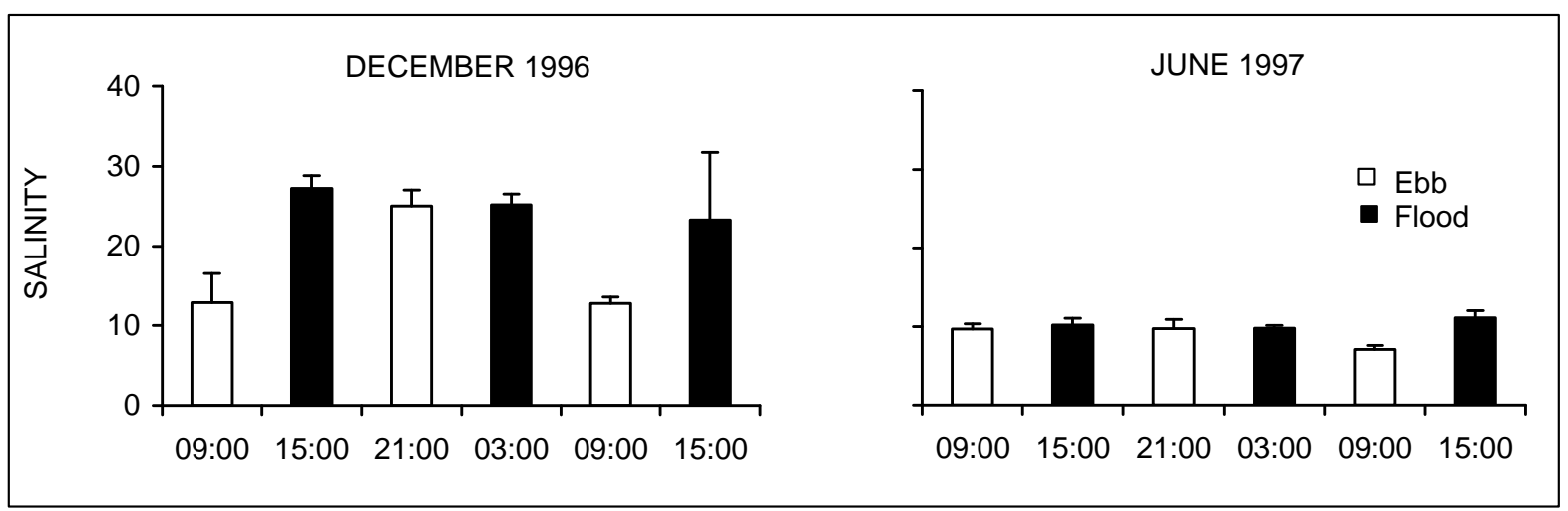

Fig. (4). Mean tidal variations of salinity of surface samples in the middle reaches of the Caeté Estuary in December 1996 and June 1997.

a massive increase in freshwater discharge. Differences in salinity among regions were observed, when compared with the seasonal and tidal changes. Lower salinity values were registered in the upper estuary and on ebb tide. Temperatures differed between seasons, sampling sites and tides (Fig. 2). Lower values were registered in the late rainy season, on ebb tide and in the upper and middle estuary, when compared with the other seasons, sites and tide.

\section{Lunar Study}

In September 1996, mean salinity values were higher on flood tides during all moon phases, with a peak at full moon (Fig. 3). High rainfall in March 1997 resulted in low salinities with no differences between tides, except at new moon due to less rain. During this moon phase, salinity was even higher than in September, possibly due to a higher sea level, as precipitation was almost equal in both months (Fig. 2 and 3).

\section{Diel Study}

In December 1996, mean salinity was lower at ebb than at flood tides, except at $21 \mathrm{~h} 00$, whereas in June 1997 salinity remained low and varied little between tides (Fig. 4).

\section{Species Composition}

\section{Tidal, Spatial and Seasonal Variation}

Higher species numbers were registered on ebb tides than on flood tides (Fig. 5 and Table 1). However, differences were only significant in the middle and lower estuary (Table 2). Tidal differences were most marked in January and February (early rainy season) in the middle and lower estuary, showing higher values on ebb tides, whereas the upper estu- ary exhibited higher species numbers on flood tides during this period (Fig. 5). Tide was a significant factor for larval density only in the middle and lower estuary (Fig. 5 and Table 2). Larval densities in these regions were significantly higher on ebb tides $(\mathrm{P}<0.001)$. Ebb tide densities were distinctly higher from February to April (early rainy season) in the middle estuary, suggesting seaward drift of larvae due to increased freshwater outflow during the rainy season (Fig. $\mathbf{5}$ and Table 2).

Species abundant in ebb tide samples in the middle estuary were Anchovia clupeoides, Stellifer microps, and Lycengraulis grossidens (Table 1). On ebb tides in the lower estuary specimens of $A$. clupeoides, Rhinosardinia amazonica and Anchoviella brevirostris predominate in the catches (Table 1). Although higher densities were registered in the upper estuary during flood tides, especially in December 1996 (late dry season) (Fig. 5 and Table 2), which may be attributed to increased larval input from seaward localities and hence accumulation of larvae, particularly of S. microps, A. clupeoides and Cynoscion acoupa (Table 1) due to low freshwater discharge in the dry season.

\section{Lunar Variation}

In September 1996 and March 1997, a total of 26,658 larvae were collected, representing 48 taxa and 21 families, respectively (Table 3). Cynoscion acoupa, Stellifer stellifer, Pimelodus blochii and an unidentified species (Species B) were relatively abundant in March 1997, but contributed little to the larval assemblage in September 1996 (Table 3). In September 1996 the larval assemblage was dominated by $S$. microps followed in order of relative abundance by $A$. clupeoides, C. acoupa, Apionichthys dumereli and Stellifer rastrifer (Table $\mathbf{3}$ ). 


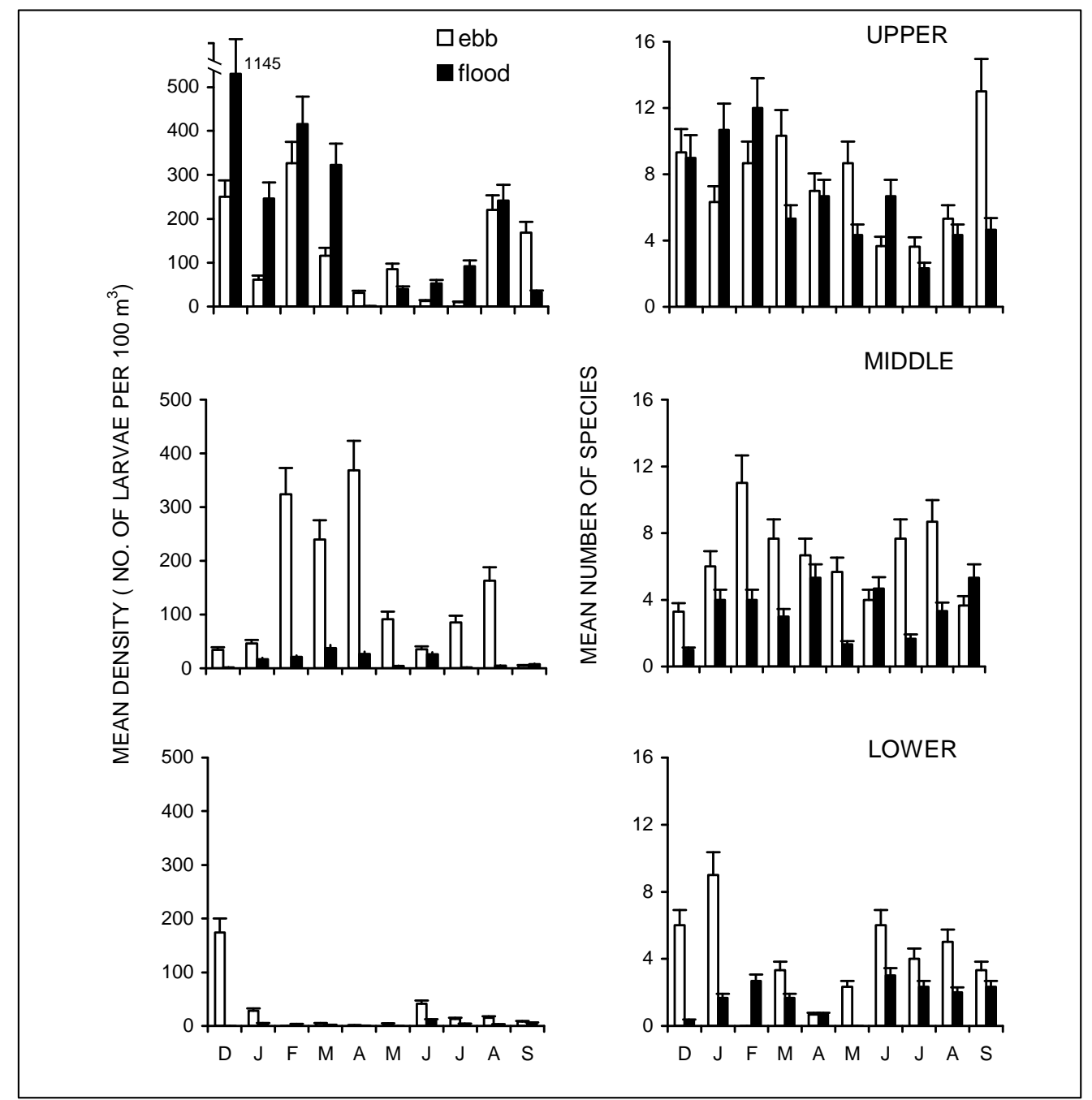

Fig. (5). Mean densities and number of species (+ s.d.) recorded in each month at the different regions of the Caeté Estuary between December 1996 and September 1997, during ebb and flood tide.

The mean number of species and densities differed significantly amongst moon phases $(\mathrm{P}<0.001)$ and the interaction terms were significant $(\mathrm{P}<0.001)$ but no significant differences were found among months. SNK tests showed that mean species numbers and densities were significantly higher during new- and first quarter moon compared with the other moon phases. Two-way ANOVAs showed that from the mean density of the most abundant 18 species, 14 differed significantly amongst moon phases $(\mathrm{P}<0.01)$ (Table 4). Month was a significant factor at $P<0.01$ for five species. The moon vs. month interaction term was also significant at $\mathrm{P}<0.01$ for 11 species. For $R$. amazonica, L. grossidens, P. blochii, Aspredo aspredo, Microgobius meeki and Micropogonias furnieri the mean squares for the interaction terms were higher than those for the most highly significant main effects (Table 4). Lunar changes were most pronounced for $C$. acoupa, where the SNK test showed that the densities during new moon were significantly greater than during the three other moon phases (Table 4). Similar lunar changes were recorded for S. rastrifer, Achirus sp., S. stellifer, Stellifer sp., R. amazonica, Aspredinichthys sp. and M. furnieri. The mean densities of $S$. microps, A. clupeoides, A. dumereli and eggs were significantly greater during first quarter moon, whereas Pseudauchnipterus nodosus and M. meeki showed higher mean densities during full moon compared with the other moon phases (Table 4).

\section{Diel, Vertical and Tidal Variation}

In December 1996 and June 1997 mean densities of 115 larvae per $100 \mathrm{~m}^{3}$, representing 31 taxa and 13 families were collected in the middle estuary (Table 5). The most abundant species in both months was A. clupeoides. Stellifer microps was prevalent in December, contributed however little to the June catch (Table 5). Rhinosardinia amazonica was recorded in moderate numbers in both months, whereas G. guavina and Achirus sp. occurred predominantly in December and Stellifer sp. and Stellifer rastrifer in June.

The mean number of species differed significantly amongst months, stratum and photoperiod $(\mathrm{P}<0.001)$ but not tides (Table 6). However, the month vs. tide and tide $v s$. photoperiod interaction terms were significant. But the mean squares for these interactions were less than those for the significant main effects. The SNK test showed that the mean numbers of species in June 1997 were significantly higher than in December 1996. In addition, significantly higher numbers of species were registered in the bottom layer than 


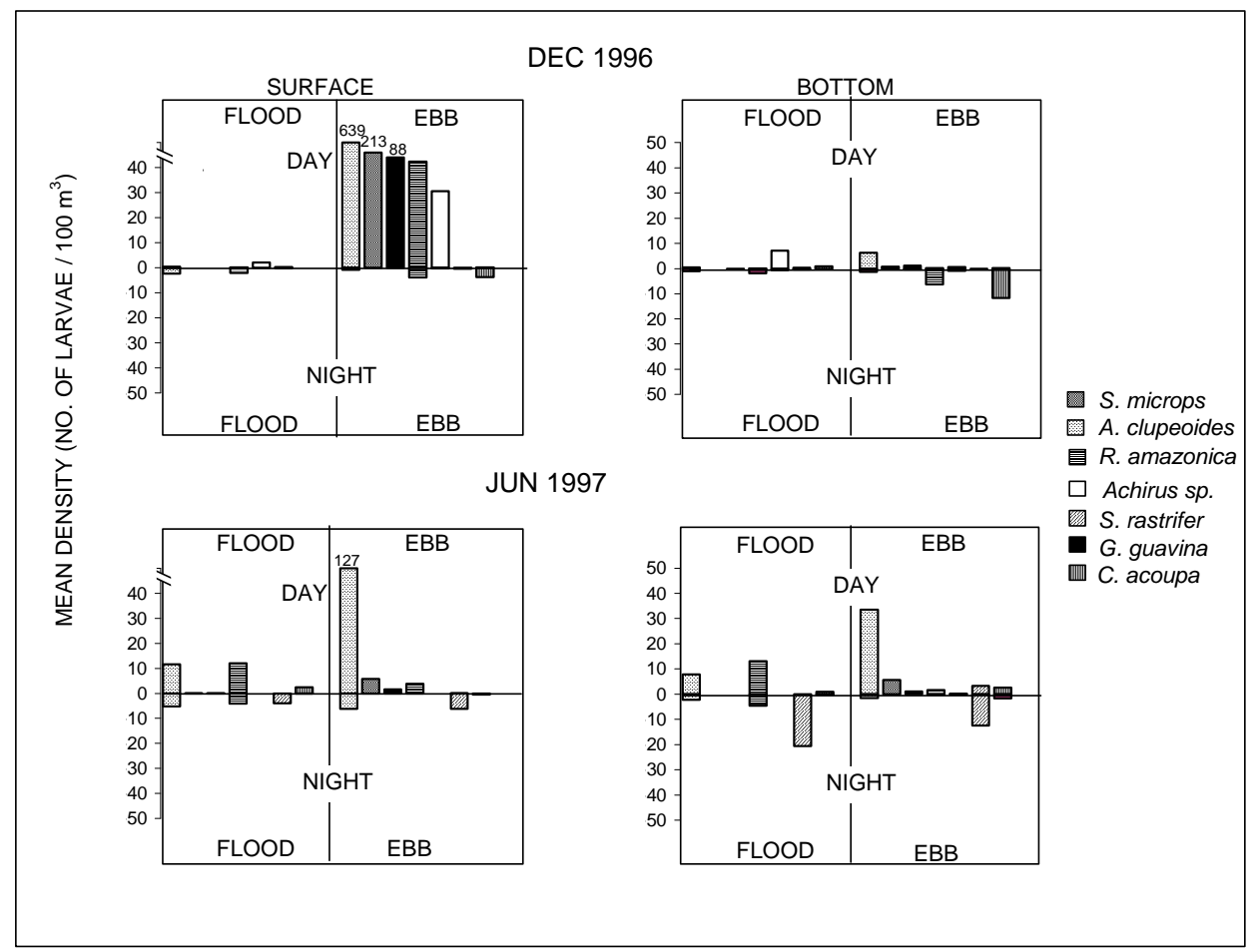

Fig. (6). Mean density in December 1996 and June 1997 in the middle estuary for the most abundant species. Data are stratified to show mean values for each paired transect with respect to surface-bottom, day-night and flood-ebb catches.

at the surface and at night than during the day (Table 6). The mean density differed significantly among months and tides ( $\mathrm{P}<0.01$ and $\mathrm{P}<0.05$, respectively) but not stratum and photoperiod and none of the interaction terms were significant (Table 6). The SNK test showed that the mean density in June 1997 was significantly higher than in December 1996 and significantly greater densities were registered on ebb tide than on flood tide (Table 6).

ANOVAs showed that the mean density of the seven most dominant species differed significantly either amongst months, stratum, tide or photoperiod (Table 7). Mean density for $S$. rastrifer $(\mathrm{P}<0.001)$ was significantly higher in June 1997 than in December 1996 (Table 7), whereas A. clupeoides and Achirus sp. dominated significantly in December 1996 ( $\mathrm{P}<0.001)$. The observed differences between ebb and flood concentrations were significant for $S$. microps, $G$. guavina, $R$. amazonica and $C$. acoupa ( $\mathrm{P}<0.05)$ (Table 7 ). These taxa displayed a trend towards larger ebb catches. Depth was a significant factor only for $S$. rastrifer and $C$. acoupa with higher catches at the bottom. However, the tide by depth interaction described the immediate relationship to tidal flow only for $C$. acoupa $(\mathrm{P}<0.05)$.

The higher catches of $C$. acoupa at the bottom and on ebb tides, suggests that retention may only apply for this species. Although not significant, most of the remaining taxa were prevalent at the surface during ebb tide, particularly in December, preventing retention of these species in the system (Fig. 6). A few larvae such as Achirus sp., S. ratrifer, $R$. amazonica and $A$. clupeoides were registered in moderate numbers on flood tides either at the bottom or surface, suggesting an upstream transport of larvae (Fig. 6). Photoperiod influenced the catches of all taxa in a consistent manner, except for $R$. amazonica and $C$. acoupa. Densities during the day significantly exceeded those taken at night for most taxa. This pattern did not emerge for $S$. rastrifer, which showed significantly higher values at night (Table 7). A response of $S$. rastrifer to light was further established by an examination of the photoperiod by depth interaction, showing higher densities at the bottom during the night. A distinct diurnal pattern, e.g. a greater tendency to stay at the bottom during the day, was however, not exhibited by S. rastrifer.

\section{Developmental Stages and Size Distribution}

\section{Tidal Influence}

Possible retention mechanisms were examined in the Caeté Estuary, investigating the percentage composition of developmental stages for the most abundant species during each tidal period (Fig. 7). Larvae of R. amazonica were almost equally present on both tides but yolk-sac and flexion larvae were more abundant on flood tides and only slightly more preflexion larvae were collected on ebb tides (Fig. 7). Larvae of G. guavina were far more abundant on flood tides which were predominated by postflexion stages whereas more flexion stages were present on ebb tides. Stellifer microps showed a similar trend to G. guavina but, additionally, a few juveniles were captured on both tides. In contrast, larvae of $C$. acoupa and A. clupeoides showed distinctly higher abundances on ebb tides than on flood tides. More postflexion larvae of $C$. acoupa were present on ebb tides while larvae of A. clupeoides were mainly preflexion (Fig. 7). Yolksac larvae of $A$. clupeoides were also sampled more on ebb tides.

\section{Lunar Influence}

Size distributions were examined to detect the occurrence of new cohorts on a small scale, which could give insight 


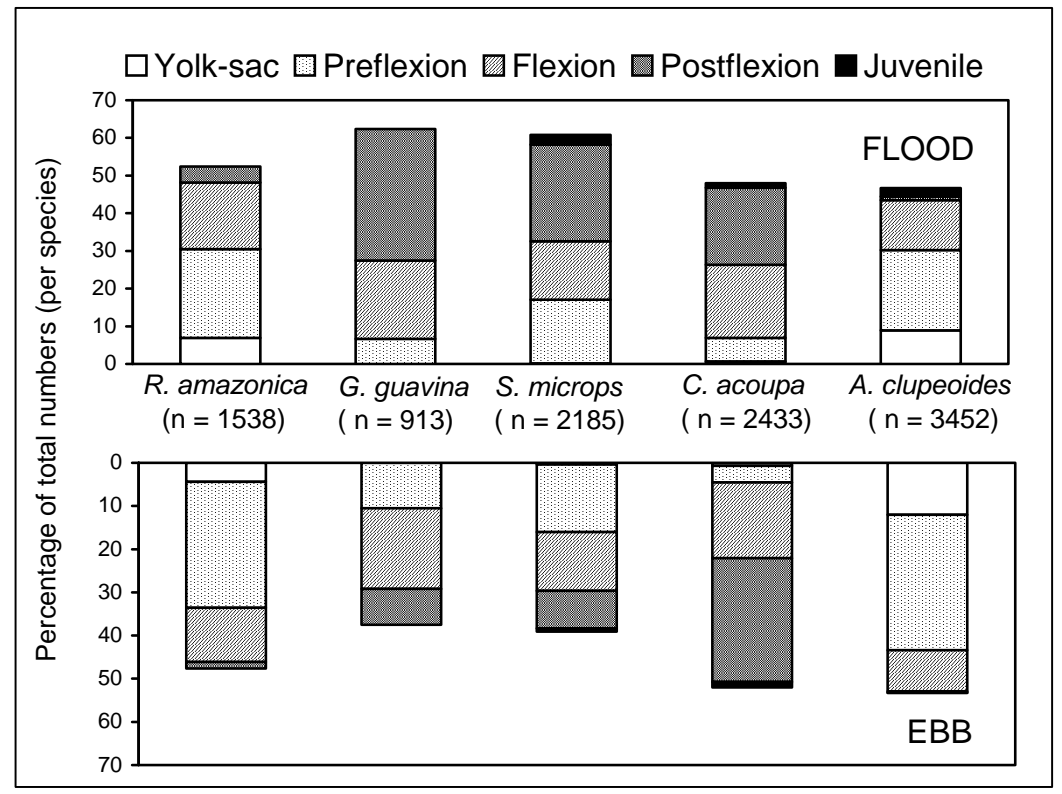

Fig. (7). Percentage compositions of developmental stages for the most abundant species in flood and ebb tides for the study period in the Caeté Estuary.

into the timing of reproduction in relation to lunar cycles and the conformity of this trend between months. Differences in the average length of $A$. clupeoides between moon phases were observed principally in September 1996 (Fig. 8), suggesting higher spawning activities during this month. The maximum increase of mean length was registered between last quarter moon and new moon in September 1996. Higher contributions of smaller larvae were observed during first quarter moon in September 1996 (Fig. 8).

A similar pattern occurred in March 1997, with the average size also decreasing significantly from new moon to first quarter moon. The appearance of a new cohort during first quarter moon in both months and the high abundance of $A$. clupeoides indicates, that spawning activities of this species may occur mainly during this moon phase.

The size distribution of $C$. acoupa differed between moon phases only in September 1996, which might be related to increase spawning in this month. The average increase in size was however registered in March 1997 from new moon to first quarter moon (Fig. 9). Highest contributions of smaller larvae during new moon in both months are in conformity with maximum larval densities and corroborate increased reproduction during this lunar period.

\section{DISCUSSION}

\section{Tidal Variation}

High larval densities occurred only in the upper estuary on flood tides, especially from December 1996 to March 1997 for species such as S. microps and A. clupeoides. This result indicates that these species utilise flood tidal currents during certain periods of the year to facilitate their entry to upstream localities. During the late rainy season, in particular in April and May, larval densities decreased markedly in the upper estuary on flood tides and became even slightly higher on ebb tides. However, these periods of no or few larvae in the upper estuary do not necessarily indicate that these species stopped spawning. It is rather a consequence of the fact that small estuarine larvae (e.g. A. clupeoides), are unable to maintain their position against tidal currents and get flushed out with the ebb tide. On the other hand, larvae of marine origin (e.g. C. acoupa), cannot penetrate to upstream localities during this period due to strong fresh water outflow. However, no distinct increase of larval density in the lower estuary could be detected during this period as observed in the Mucuri River [31]. One possible explanation is that the young larvae disperse to less productive and inhospitable environments in offshore areas and may subsequently die from starvation. Moreover, sudden increases in freshwater inflow may cause mortalities of young fish unable to avoid low-salinity waters [32]. In contrast to the upper estuary, the overall densities in the middle and lower estuary were higher on ebb tides for all abundant species throughout the study period. According to personal observations, the Caeté Estuary is a shallow ebb-dominated system, characterised by tidal currents with shorter and stronger ebb and a longer and weaker flood tide. These forces could aggravate the retention of larvae especially in the middle and lower estuary.

It has been previously stated that, in cases where an estuary is completely flushed on ebb tide, no permanent plankton will develop [33]. In the open estuary of the present study, all species were present on both flood and ebb tides at a range of developmental stages, which indicates that the larvae are not retained in the system. However, the export of fish larvae on an outgoing ebb tide appears to be related to developmental stage. Larvae of G. guavina and S. microps, for example, were most abundant on flood tides at the postflexion stage, suggesting a net input of larvae into the estuary, whereas not so large individuals were found on ebb tides. This suggests that older individuals were being recruited to and possibly retained in the estuary. On the other hand, the density of postflexion stages of $R$. amazonica and A. clupeoides were low on flood and ebb tides, which might be related to possible under sampling due to aggregating 

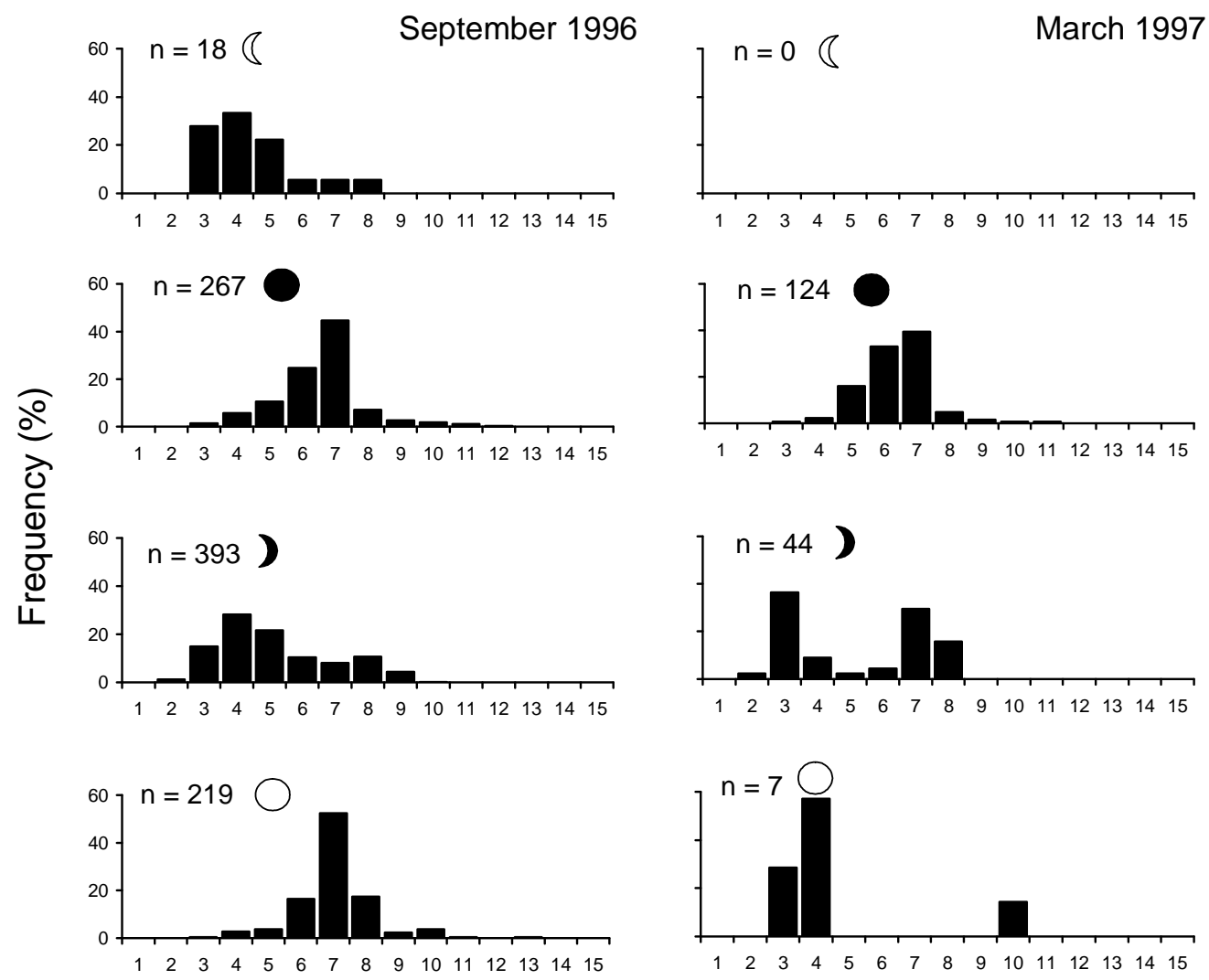

Standard length $(\mathrm{mm})$

Fig. (8). Size distribution of Anchovia clupeoides in the upper estuary during different moon phases in September 1996 and March 1997.

behaviour during this stage. Larger numbers of early larvae (yolk-sac, preflexion) of the latter species were passively swept out of the estuary on ebb tides. In contrast, larvae of $C$. acoupa were prevalent on ebb tides at the postflexion stage, showing less capability to remain in the system. It is however possible that relatively few larvae settle out on each tidal cycle, so that densities did not change by a significant amount, as proposed in the literature [34]. These results emphasise that the tidal movement of larval fish cannot be summarised as a single group, but rather as individual taxa at different larval stages.

\section{Lunar Variation}

Many fish display peak reproductive activity around new or full moon, while other variations in reproductive patterns have also been shown [35]. Lunar periodicity affected 10 species in Puerto Rico where tidal ranges are low [36]. In North Australia, three species were affected by lunar phase during spring tides [37]. Previous works reported that the timing of recruitment of Caribbean reef fishes was determined by regular lunar cycles acting on the production of larvae [38].

Up to now, moon-phase effects on larval fish assemblages in estuaries have been little studied. From the quantitative assessment in the Caeté Estuary, it was difficult to determine the effect of lunar related reproductive rhythms on species abundance. Lunar periodicity per se does not seem to affect the larval fish assemblage in the Caeté Estuary. Environmental variability, in part associated with lunar periodic- ity, may account for weekly fish abundance variability. These short-term variations might be related to the displacement of different water masses and their associated plankton. High tidal range characterised the new moon phase during flood tide in March 1997, resulting in higher species number and a net input of larvae such as $C$. acoupa from nearshore. In the following moon phases in March 1997, salinity decreased markedly due to heavy rainfall and reduced pulses of inshore water caused a clear decrease of larval abundance, particularly $C$. acoupa. Higher tides might provide greater assistance for the upstream movement of larval fish such as C. acoupa and also enables the larvae to penetrate further into upper reaches of the estuary. The higher contribution of smaller larvae of $C$. acoupa during new moon in both months corroborates that reproduction and recruitment of early stages into the estuary is increased during this lunar period. The situation of $C$. acoupa contrasts with that of $A$. clupeoides, showing highest abundance when sea level is lowest during first quarter moon in particular in September 1996. Such may be attributed to their estuarine life cycle and to a reduced seaward drift of young larvae during calmer current conditions. In addition, a higher contribution of smaller larvae was observed during first quarter moon in both months, suggesting that spawning activities of this species occurs mainly during this moon phase.

\section{Vertical Variation}

The horizontal distributions of larval fish assemblages are complex because they are not only influenced by physi- 

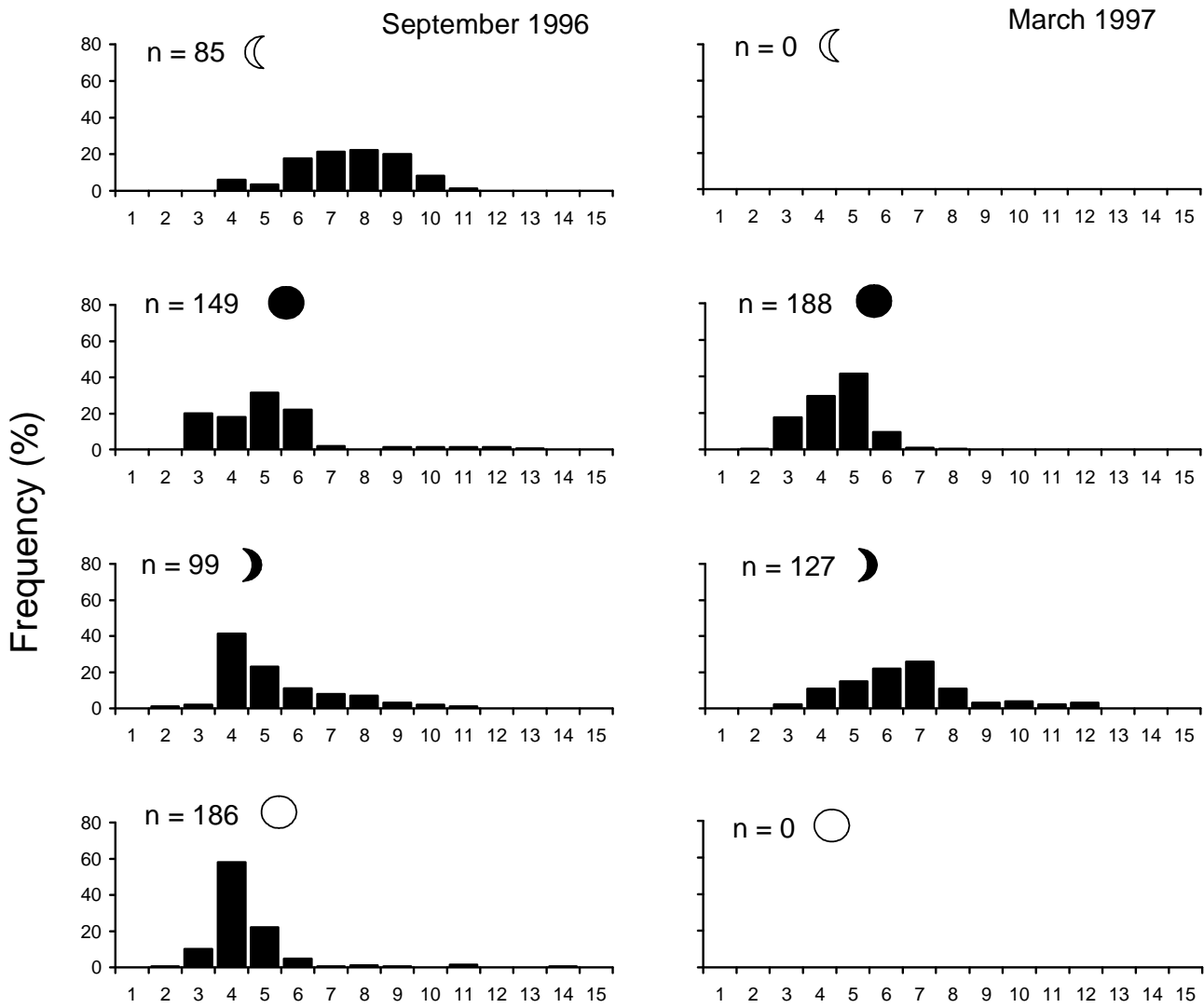

\section{Standard length $(\mathrm{mm})$}

Fig. (9). Size distribution of Cynoscion acoupa in the upper estuary during different moon phases in September 1996 and March 1997.

cal processes, but also by behavioural patterns. Larval stages of estuarine fishes are often stratified within the water column and many are abundant near the bottom to avoid being flushed out with the ebb tide [2]. However, vertical distribution patterns may vary considerably within the same species according to the sampling place and time, as evidenced by the variation of the vertical distribution of the most abundant species between December 1996 and June 1997. Other works found that vertical distribution of different size classes showed considerable variation in some species [39]. This emphasises the importance of examining developmental state of the different species in larval studies. It has been shown [40] that with the formation of rod-cells in the eyes (e.g. with $10 \mathrm{~mm}$ for E. mordax according to [41]) the larvae start vertical migration. This physiological reason seems to explain the significant difference between layers for $S$. rastifer and $C$. acoupa, since they were the only species collected with more individuals larger than $10 \mathrm{~mm}$. The fact that almost no postflexion stages and juveniles from the other species were collected in the 30-h study might account for the lack of significant differences between both layers.

Apart from this, vertical migrations are an unlikely factor in the Caeté Estuary, as depth was generally less than $5 \mathrm{~m}$, and the water appeared to be well mixed by turbulence and not stratified showing the same current direction throughout the water column [11]. No evidence of vertical stratification of fish larvae relative to diel and tidal cycles was found in a well mixed estuary in New Zealand [34]. In shallow-water areas, even benthic particles will be transported to the sur- face by turbulence, and may remain there by surface tension [42]. Furthermore, the authors found that the ecological differences between the uppermost and lower layers are reduced in turbid waters, where visual feeding is restricted to light at the surface because of high reflection of light and low penetration of radiation [42]. The authors observed that early stages require high light-intensities to find their prey. So, small larvae feed at the surface during the day, while older specimens are able to hunt in deeper layers. This appears true for the Caeté Estuary, since most young larvae were found particularly at the surface. Previous work in mangrove areas along the coast of Thailand [43] has also shown that fish larvae were more abundant at the surface than at the bottom.

\section{Diel Variation}

Diel changes in estuarine ichthyoplankton abundance have been documented by several authors [44-47] and the differences in catches between night and day periods can be attributed to many factors. [34] found that fish larval densities were significantly higher in night collections than day collections, which was partly explained by gear avoidance of some larvae, especially larger engraulids caught at night. Visual perception does not necessarily plays a role in net avoidance of herring larvae during the day, but swimming activity and alertness are important [48]. Gear avoidance seems to be negligible in the Caeté Estuary due to the high turbidity in the system and the fact that overall density was not significantly different between day and night catches. 
However, when considering single species, it was found that most species present during the day showed a marked reduction in number during the night, except for S. rastrifer. Apparently, $S$. rastrifer avoided the net during the daylight, since more larvae were caught during the night, especially larger larvae. It is not clear whether these larger larvae were only caught because they were weak or starving individuals. The higher densities of the remaining species during the daytime was attributed to a lack of escape response during the day due to the presence of mainly young larvae during the entire $30 \mathrm{~h}$-study. Diurnal variation in abundance of the remaining species may also be related to differences in activity rhythms which might be associated with feeding strategy [36]. Species such as A. clupeoides, S. microps, R. amazonica, Achirus sp. and G. guavina were generally prevalent during the day and occurred predominantly at the surface on ebb tides. The aforementioned species were mainly represented by early larval stages. Feeding activity of these species seems to take place particularly during morning hours, since afternoon catches were low in both months. On the other hand, species such as $S$. rastrifer and $C$. acoupa represented by older stages showed higher densities at night and were mainly present at the bottom layer and on flood tides.

Selective tidal stream transport is not a feature of the Caeté Estuary. The only possibility for fish larvae carried into the system on flood tides to remain in the estuary on ebb tide, would be to move laterally to areas of low tidal velocities $e . g$. the river banks [49] during slack water taking advantage of the reduced turbulence. An investigation comparing the ichthyoplankton near the channel banks with the mainstream, is however necessary to confirm this theory.

\section{ACKNOWLEDGEMENTS}

This study was undertaken within the framework of the 'Mangroves Dynamics and Management' (MADAM), supported by the Ministry for Education, Science, Research and Technology (BMBf) (Project number: 03F0154A) - Germany and; 'Conselho Nacional de Desenvolvimento Cietífico e Tecnológico' (CNPq) - Brazil. The project was coordinated by the Centre for Tropical Marine Ecology (ZMT) - Bremen (Germany), Universidade Federal do Pará (UFPA) and Museu Paraense Emílio Goeldi (MPEG) - Brazil. Dr. F.W. Kurtz and Dr. J.G. Ditty are thanked for their help in the identification of some fish larvae. Prof. Stephen J.M. Blaber and Dr. Monica F. Costa are thanked for their help in preparing this version of the MS.

\section{SUPPLEMENTARY MATERIAL}

Supplementary Material can be viewed at www.bentham.org/open/tofishsj

\section{REFERENCES}

[1] Creutzberg F. In: Autrum H, Bünning E, von Frisch K, et al. Ergebnisse der Biologie, 26. Springer-Verlag, 1963; 118-27.

[2] Weinstein MP, Weiss SL, Hodson R, Gerry LR. Retention of three taxa of postlarval fishes in an intensively flushed tidal estuary, Cape river, North Carolina. Fish Bull 1980; 78(2): 419-35.

[3] Fortier L, Leggett WC. Fickian Transport and the Dispersal of Fish Larvae in Estuaries. Can J Fish Aquat S 1982; 39: 1150-63.

[4] Pritchard DW. Estuarine circulation patterns. Proc Am Soc Civil Eng 1955; 81: 1-11.
[5] Boehlert GW, Mundy BC. Roles of behavioural and physical factors in larval and juvenile fish recruitment to estuarine nursery areas. Am Fish Soc Symp 1988; 3: 51-67.

[6] Norcross BL, Shaw RF. Oceanic and Estuarine Transport of Fish Eggs and Larvae: a review. Trans Am Fish Soc 1984; 113: 153-65.

[7] McCleave JD, Wippelhauser GS. Behavioural aspects of selective tidal stream transport in juvenile American eels. Am Fish Soc Symp 1987; 1: 138-50.

[8] Barletta Bergan A, Barletta M, Saint Paul U. Structure and seasonal dynamics of larval fish in the Caeté River Estuary in North Brazil. Estuar Coast Shelf S 2002a; 54: 193-206.

[9] Barletta Bergan A, Barletta M, Saint Paul U. Community structure and temporal variability of ichthyoplankton in North Brazilian mangrove creeks. J Fish Biol 2002b; 61(A): 33-51.

[10] Barletta M, Barletta-Bergan A, Saint-Paul U, Hubold G. The role of salinity in structuring the fish assemblages in a tropical estuary. $\mathrm{J}$ Fish Biol 2005; 66, 45-72.

[11] Dittmar T. Outwelling of organic matter and nutrients from a mangrove in North Brazil: evidence from organic tracers and flux measurements. Ph.D. Thesis. Zentrum für Marine Tropenökologie. University of Bremen: Bremen 1999.

[12] Cervigón F In: Yáñez-Arancíbia A, Ed. Fish community ecology in estuaries and coastal lagoons: Towards an ecosystem integration. UNAM Press 1985; 57-78.

[13] Cervigón F Los peces marinos de Venezuela. Fundación Científica los Roques Caracas: Caracas 1991: vol. I.

[14] Cervigón F Los peces marinos de Venezuela. Fundación Científica los Roques Caracas: Caracas 1993: vol. II.

[15] Cervigón F Los peces marinos de Venezuela. Fundación Científica los Roques Caracas: Caracas 1994; vol. III.

[16] Cervigón F Los peces marinos de Venezuela. Volume IV. Fundación Científica los Roques Caracas: Caracas 1996.

[17] Chao LN. A basic for classifying Western Atlantic Sciaenidae (Teleostei: Perciformes). NOAA Technical Report, NMFS Circular 4151978.

[18] Ditty JG, Shaw RF. Preliminary guide to the identification of the early life history stages of sciaenid fishes from the Western Central Atlantic. NOAA Technical Memorandum NMFS -SEFSC-349 1994.

[19] Faroogi T, Shaw RF, Ditty JG. Preliminary guide to the identification of the early life history stages of anchovies (Familiy Engraulidae) of the Western Central Atlantic. NOAA Technical Memorandum NMFS - SEFSC - 3581995.

[20] Figueiredo JL, Menezes NA. Manual de peixes marinhos do Sudeste do Brasil. II Teleostei, 1. Museu de Zoologia da Universidade de São Paulo: São Paulo 1978.

[21] Figueiredo JL, Menezes NA. Manual de peixes marinhos do Sudeste do Brasil. III Teleostei, 2. Museu de Zoologia da Universidade de São Paulo: São Paulo 1980.

[22] Fischer W. FAO species identification sheets for fisheries purposes. Western Central Atlantic, 1-5. Food and Agriculture Organisation: Rome 1978.

[23] Menezes NA, Figueiredo JL. Manual de peixes marinhos do Sudeste do Brasil. IV Teleostei, 3. Museu de Zoologia da Universidade de São Paulo: São Paulo 1980.

[24] Menezes NA, Figueiredo JL. Manual de peixes marinhos do Sudeste do Brasil. V Teleostei, 4. Museu de Zoologia da Universidade de São Paulo: São Paulo 1985.

[25] Moser HG, Richards WJ, Cohen DM, Fahay MP, Kendall Jr. AW, Richardson SL. Ontogeny and Systematics of fishes. American Society of Ichthyologists and Herpetologists Special Publication $1984 ; 1$.

[26] Sinque C. Larvas de Sciaenidae (Teleostei) identificados na região estuarino-lagunar de Cananéia. Bol Zoo Univ São Paulo 1980; 5: 39-77.

[27] Weiss G. Ictioplâncton do estuário da Lagoa dos Patos, Brazil. PhD. Thesis. Universidad Nacional de la Plata: La Plata 1981.

[28] Whitehead PJP, Nelson GJ, Wongratana T. FAO species catalogue 7. Clupeoid fishes of the world. An annotated and illustrated catalogue of the herrings, sardines, pilchards, sprats, anchovies, and wolf herrings. Part 2, Engraulidae. FAO Fishe Symp Synop 1988; 125(7): 305-579.

[29] Ahlstrom EH. Ball OP Description of eggs and larvae of jack mackerel (Trachurus symmetricus) and distribution and abundance of larvae in 1950 and 1951. Fish Bull 1954; 56: 209-45. 
[30] Underwood AJ. Experiments in Ecology. Their logical design and interpretation using analysis of variance. Cambridge University Press: Cambridge 1997.

[31] Castro M. Boncker ACT Ocorrência de larvas de peixe no sistema estuarino de Rio Mucuri (BA). Arq Biol Tecnol 1995; 39: 171-85.

[32] Moyle PB, Cech Jr. JJ Fishes. An introduction to ichthyology. 2nd ed. Prentice-Hall, Englewood Cliffs: 1988.

[33] Rogers HM. Occurrence and retention of plankton within the estuary. J Fish Res Board Can 1940; 5: 164-71.

[34] Roper DS. Occurrence and recruitment of fish larvae in northern New Zealand estuary. Estuar Coast Shelf S 1986; 22: 705-17.

[35] Johannes RE. Reproductive strategies of coastal marine fishes in the tropics. Environ Biol Fish 1978; 2: 65-84.

[36] Davis TLO. Temporal changes in the fish fauna entering a tidal swamp system in tropical Australia. Environ Biol Fish 1988; 21(3): 161-72.

[37] Rooker JR, Dennis GD. Diel, lunar and seasonal changes in a mangrove fish assemblage off Southwestern Puerto Rico. Bull Mar S 1991; 49(3): 684-98.

[38] Robertson DR, Green DG, Victor BC. Temporal coupling of production and recruitment of larvae of a Caribbean reef fish. Ecology 1988; 69: 370-81.

[39] Blaxter JHS, Hunter JR. The biology of the clupeoid fishes. Adv Mar Biol 1982; 20: 3-223.

[40] Sandy JM, Blaxter JHS. A study of retinal development in larval herring and sole. J Mar Biol Ass UK 1980; 60: 59-71.
[41] O'Conell CP. Development of organ systems in the northern anchovy, Engraulis mordax and other teleosts. Am Zoo 1981; 21: 429-46.

[42] Hempel G, Weikert $\mathrm{H}$. The neuston of the subtropical and boreal North-eastern Atlantic Ocean. A review. Mar Biol 1972; 13: 70-88.

[43] Janekarn V, Boonruang P. Composition and occurrence of fish larvae in mangrove areas along the east coast of Phuket Island, western peninsular, Thailand. Phuket Mar Biol Res Bull 1986; 44: $1-22$.

[44] Bridger JP. On day and night variation in catches of fish larvae. J Conseil 1956; 22: 42-57.

[45] Fore PL, Blaxter KN. Diel fluctuations in the catch of larval Gulf menhaden, Brevoortia patronus, at Galveston Entrance, Texas. Trans Am Fish Soc 1972; 101: 729-32.

[46] Elridge MB. Factors influencing distribution of fish eggs and larvae over eight 24-h samplings in Richardson Bay, California. Calif Fish Game 1977; 63: 101-16.

[47] Kendall AW, Naplin NA. Diel-depth distribution of summer ichthyoplankton in the middle Atlantic Bight. Fish Bull 1981; 79: 70526.

[48] Soewito P, Schalk PH. Spatial and seasonal patterns in fish larvae distribution in the Banda Sea (Indonesia). Neth J Sea Res 1990; 25(4): 591- 600.

[49] Lewis RM, Mann WC. Occurrence and abundance of larval Atlantic menhaden, Brevoortia tyrannus, at two north Carolina inlets with notes on associated species. Trans Am Fish Soc 1971; 100: 296-301.

Received: September 05, 2008

(C) Barletta and Barletta-Bergan; Licensee Bentham Open.

This is an open access article licensed under the terms of the Creative Commons Attribution Non-Commercial License (http://creativecommons.org/licenses/by-nc/3.0/) which permits unrestricted, non-commercial use, distribution and reproduction in any medium, provided the work is properly cited. 